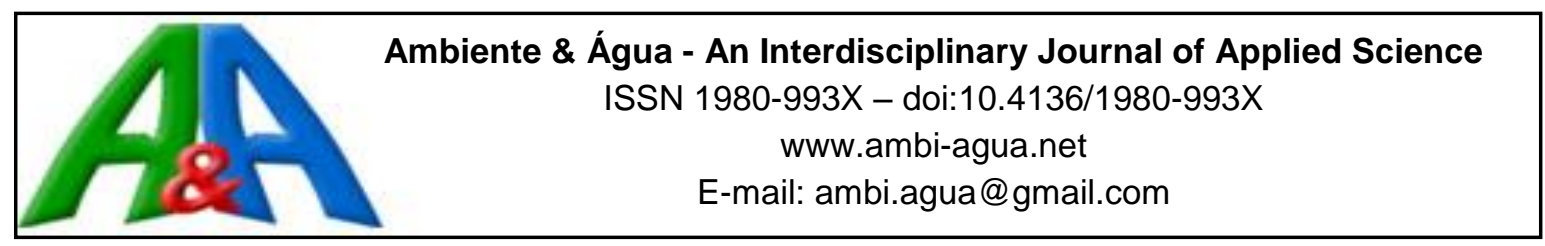

\title{
Continuous electrochemical reactor improved by the addition of Moringa oleífera lam extract: optimization of operational conditions for Blue $5 \mathrm{G}$ dye removal
}

\author{
ARTICLES doi:10.4136/ambi-agua.2290
}

Received: 10 Jun. 2018; Accepted: 06 Feb. 2019

\author{
Bruna Souza dos Santos ${ }^{(D)}$; Eduardo Eyng*iD; \\ Paulo Rodrigo Stival Bittencourt ${ }^{D}$; Laercio Mantovani Frare ${ }^{D}$; \\ Éder Lisandro de Moraes Flores ${ }^{(D}$; Michelle Budke Costa \\ Universidade Tecnológica Federal do Paraná (UTFPR), Medianeira, PR, Brasil \\ Programa de Pós-Graduação em Tecnologias Ambientais (PPGTAMB). \\ E-mail: brusouzasantos@hotmail.com, eduardoeyng@utfpr.edu.br,paulob@utfpr.edu.br, \\ laercio@utfpr.edu.br, eder@utfpr.edu.br,michelleb@utfpr.edu.br \\ *Corresponding author
}

\begin{abstract}
Wastewaters from textile industries are known for their difficulty to treat, several alternative technologies are applied for their treatment. In this context, the study examined a hybrid treatment system, composed of electrocoagulation combined with a natural coagulant (extract of Moringa oleífera lam seeds) to remove reactive dye Blue 5G aqueous solutions. The work evaluated the use of milder operating conditions to improve the efficiency of treatment, with reduced demands for electrical power and coagulant. The following factors were evaluated: electric current intensity, natural coagulant concentration and hydraulic retention time. A quadratic model was adjusted and validated at a 5\% significance level. The overall optimization resulted in conditions of $0.28 \mathrm{~A}$ for electrical current intensity, $1000.00 \mathrm{mg} \mathrm{L}^{-1}$ of aqueous extract of Moringa oleífera lam and $5 \mathrm{~min}$ for hydraulic retention time. While operating under optimal conditions, the removal of $71.38 \%$ of color and $5.22 \mathrm{mg} \mathrm{L}^{-1}$ of iron residual concentration was achieved.
\end{abstract}

Keywords: central composite rotational design, global optimization of processes, natural coagulant, textile effluent, wastewater electrochemical treatment.

\section{Reator eletroquímico contínuo potencializado pela adição de extrato de Moringa oleífera lam: otimização das condições operacionais para remoção do corante Blue 5G}

\section{RESUMO}

Os efluentes das indústrias têxteis são conhecidos pela dificuldade de tratamento, constituindo um campo de aplicação de tecnologias alternativas para o tratamento. Neste contexto, um sistema de tratamento híbrido, composto por eletrocoagulação associada à adição de coagulante natural (extrato de sementes de Moringa oleífera lam), visa utilizar condições de operação mais suaves, que proporcionem eficiência de tratamento, com menor demanda de energia elétrica e coagulante. Assim, a remoção do corante reativo Azul 5G de soluções aquosas 
foi estudada. Foram avaliados os efeitos dos fatores: intensidade da corrente elétrica, concentração de coagulantes naturais e tempo de retenção hidráulica. Um modelo quadrático foi ajustado e validado no nível de significância de 5\%. A otimização global resultou em condições de 0,28 A para intensidade de corrente elétrica, $1000,00 \mathrm{mg} \mathrm{L}^{-1}$ de extrato aquoso de Moringa oleífera lam e 5 min para tempo de retenção hidráulica. Operando em condições ótimas, observou-se 71,38\% de remoção de cor e 5,22 $\mathrm{mg} \mathrm{L}^{-1}$ de concentração residual de ferro.

Palavras-chave: coagulante natural, delineamento composto central rotacional, efluentes têxteis, otimização global de processos, tratamento eletroquímico de águas residuárias.

\section{INTRODUCTION}

Despite current technological developments, many there are still many problems due to contamination and water pollution of waters. The development and improvement of technologies for effluent treatment are needed, not only from the perspective of the technical feasibility of pollutant removal, but also from the social-environmental viewpoint, since the minimization of treatment system waste is an important factor.

Industrial textile effluent is characterized by low biodegradability and relative toxicity. The study of alternative treatment technologies is therefore very important, since this sector consumes large volumes of water, and the need to reuse this water becomes increasingly important.

Among the physical-chemical treatment technologies of effluents, electrocoagulation is an interesting option. The technique can be more efficient than the coagulation/flocculation process normally used. This process uses the basic foundation of coagulation/flocculation, producing redox reactions, and also generates micro bubbles that ascend and eventually interact with whole system. The result is flocculation and flotation of the pollutant as a sludge, and consequently, optimization of treatment process effectiveness (Aquino Neto et al., 2011).

There are in literature several studies that report the effectiveness of wastewater treatment by electrocoagulation, particularly, applications on textile effluent treatment (Pajootan et al., 2012; Daneshvar et al., 2006). In this context, electrocoagulation technology had been combined with other treatment technologies, such as, ozone (Asaithambi et al. 2012; Song et al., 2007), fenton (Yavuz et al., 2014), ultrasound agitation (Raschitor et al., 2014; Vianney e Muthukumar, 2016) and adsorption (Secula et al., 2012).

Another interesting work evaluated the efficiency of electrocoagulation process assisted by Opuntia ficus indica pad juice. The natural coagulant addition provided a $15.1 \%$ increase in turbidity removal from a synthetic solution (tap water with $300 \mathrm{mg} \mathrm{L}^{-1}$ and silica gel (Adjeroud et al., 2015). Chemical coagulation and electrocoagulation techniques also have been explored for the removal of organic compounds from slaughterhouse effluent. The results showed that combined processes are inferred to be superior to electrocoagulation alone (Bazrafshan et al., 2012).

Still in the field of alternative technologies for effluents treatment, the employment of the seed of Moringa Oleífera Lam as a natural coagulant deserves to be highlighted. The Moringa Oleífera Lam seed acts as an effective coagulant agent because it contains a cationic protein of low molecular weight which interacts with the organic material of the effluent, destroying the stability of colloidal structures and facilitating the removal of the material by sedimentation (Arantes et al., 2012).

The analysis of the chemical composition of Moringa Oleífera Lam seeds reveals that the pulp contains proteins of low molecular weight and dissolution in water favors the attachment of colloids due to the neutralization of surface charges. The main reason for this coagulant action is the formation of bridges between the particles in suspension and specific organic

Rev. Ambient. Água vol. 14 n. 3, e2290 - Taubaté 2019 
molecules present in Moringa Oleífera Lam extract (Barreto et al., 2009).

The extract of Moringa Oleífera Lam has shown excellent performance for water clarification, reaching 90-94\% of turbidity removal. This result is similar to substances traditionally used, such as Aluminum Sulphate $\left(\mathrm{Al}_{2}\left(\mathrm{SO}_{4}\right)_{3}\right)$, Ferric Chloride $\left(\mathrm{FeCl}_{3}\right)$ and Ferrous Sulphate $\left(\mathrm{FeSO}_{4}\right)$ (Paterniani et al., 2009). Extracts from the pulp and the shell of the seed were also used for iron oxide removal from rainwater (Carvalho et al., 2006).

The combination of these two techniques, electrocoagulation and the addition of a natural coagulant based on Moringa Oleífera Lam, as an hybrid system, may constitute a promising application for the treatment of textile effluent. This work therefore applied the hybrid treatment system to removal of reactive dye Blue $5 \mathrm{G}$ from aqueous solutions to evaluate whether the association of these treatment technologies, operated under milder treatment conditions, may provide an increase of performance.

\section{MATERIALS AND METHODS}

\subsection{Analytical methodologies}

The dye solutions used were prepared from the commercial reactive dye Blue $5 \mathrm{G}$, with a concentration of $50 \mathrm{mg} \mathrm{L}^{-1}$. Sodium Chloride was added to a concentration of $1 \mathrm{~g} \mathrm{~L}^{-1}$ to increase the solution electrical conductivity.

The color evaluation of samples was performed by light absorption (peak height) at $618 \mathrm{~nm}$, which was previously determined by spectrum scanning on a PerkinElmer Spectrophotometer, dual beam, Lambda 45 model. This wavelength is in agreement with results reported in literature (Lambrecht et al., 2015). Color removal was assessed by comparing the absorbance of the samples with treatment and without it.

The determination of the concentration of residual iron was carried out through spectrometry atomic absorption flame, using the direct method of air-acetylene flame. Before the residual iron determination, the samples were prepared by acid digestion. Therefore, $50 \mathrm{~mL}$ of sample was transferred to an Erlenmeyer and $5 \mathrm{~mL}$ of nitric acid $\left(\mathrm{HNO}_{3}\right)$ was added. The digestion was heated until the volume was reduced to $20 \mathrm{~mL}$. The digested sample was transferred to a volumetric flask, and distilled water was added until the volume of $50 \mathrm{~mL}$ was reached. Atomic absorption measurements used the following conditions: Acetylene flow = $2 \mathrm{~L} \mathrm{~min}^{-1}$; Air flow $=13.5 \mathrm{~L} \mathrm{~min}^{-1}$; Lamp current $=10 \mathrm{~mA}$; wave length $248.3 \mathrm{~nm}$ and slit $=$ $0.2 \mathrm{~m}$. The dilution of standard iron solution followed the concentrations: $0.5 ; 1.0 ; 2.5 ; 5.0$ and $10.0 \mathrm{mg} \mathrm{L}^{-1}$.

\subsection{Method for obtain the extract of Moringa oleífera lam seed}

The Moringa Oleífera Lam (MO) seeds used in this work, which were selected for uniformity in size and coloring, were from the municipality of Medianeira- PR Brazil, Latitude: 25 17'43" S and Longitude: 54 05'38" W and Marechal Cândido Rondon - PR Brazil, Latitude: 24 33'22" S and Longitude: 54 03'24" W.

Initially, the husks of MO seeds were removed and manually macerated so that a homogeneous material was obtained. This material was used in a natural coagulant solution preparation at a ratio of $5 \mathrm{~g}$ of MO to $100 \mathrm{~mL}$ of saline aqueous solution (20\% sodium chloride concentration). This solution was then agitated for $20 \mathrm{~s}$ in an ultrasonic bath, at $80 \mathrm{kHz}$ frequency and $150 \mathrm{~W}$ of power. After the extraction stage was finished, the solution was subjected to a vacuum filtration with filter paper of a 3-micrometer pore. After this procedure, the resulting solution can be used in coagulation/flocculation tests, presenting a ratio of $50.000 \mathrm{mg} \mathrm{L}^{-1}$ (solution matrix of coagulant). 


\subsection{System of treatment hybrid}

Figure 1 is a schematic of the treatment system for synthetic textile effluent (reactive dye Blue 5G solution) operating under continuous flow, employing electrocoagulation technology as a hybrid arrangement with the addition of aqueous extract of Moringa oleífera lam seed.

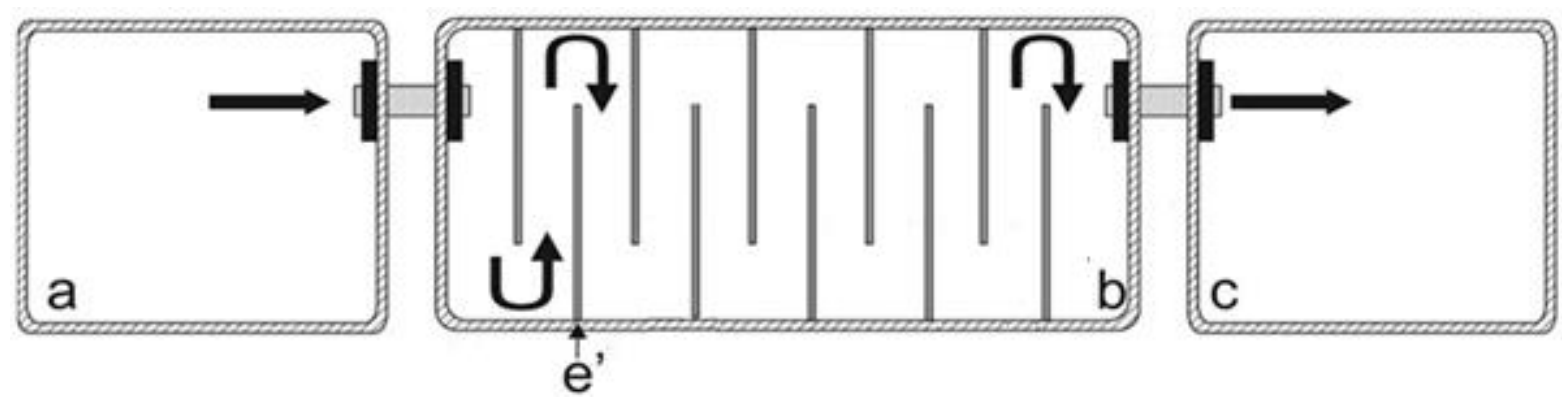

Figure 1. Schematic of the hybrid treatment system.

In first compartment, "a", the aqueous extract of Moringa oleiffera lam seeds is mixed with dye reactive Blue $5 \mathrm{G}$ solution for a period of $3 \mathrm{~min}$ under high agitation. This section is equipped with a spindle, driven by a $12 \mathrm{~V}$ engine. The effluent is then pumped to the electrolytic chamber, "b" (18.5 cm of width x $58 \mathrm{~cm}$ of length $\mathrm{x} 20 \mathrm{~cm}$ of height, with effective volume of $16 \mathrm{~L})$. In this compartment, the effluent comes into contact with iron sacrifice electrodes, which have two purposes: the viability of electrocoagulation, providing $\mathrm{Fe}^{3+}$ ions to solution, and also working as baffles, which help the hydraulic system. Finally, the treated effluent flows to the camera, "c", where it is stored. For the electrochemical treatment, the electrodes are connected to a DC-power source, in a parallel mode. Five pairs of iron electrodes were used, with a total area of $512 \mathrm{~cm}^{2}$.

After the tests of electrocoagulation associated with addition of aqueous extract of Moringa Oleífera Lam, samples of treated effluent were collected in duplicate, and after an hour of stabilization were subjected to chemical analyses for color removal evaluation and determination of residual iron concentration.

\subsection{Experimental Design}

The effects of electric current intensity (I), concentration of Moringa Oleífera Lam coagulant (MO) and hydraulic retention time (HRT) on percentage color removal and concentration of residual iron on treated reactive dye Blue $5 \mathrm{G}$ solutions, were evaluated by a Central Composite Rotational Design - CCRD.

According to experimental design CCRD, $2^{3}$ factorial tests were performed, with three repetitions at central point condition, and six tests were performed at axial points, totaling 17 runs, which were carried out in duplicate. The real values, corresponding to the range of the study variables, are presented in Table 1.

Table 1. Real and coded values corresponding to factors studied.

\begin{tabular}{lccccc}
\hline & -1.68 & -1 & 0 & 1 & +1.68 \\
\hline I (A)* & 0.10 & 0.28 & 0.55 & 0.82 & 1.00 \\
MO (mg L & 100.0 & 282.1 & 550.0 & 817.9 & 1000.0 \\
HRT (min) & 5.0 & 6.0 & 7.5 & 9.0 & 10.0 \\
\hline
\end{tabular}

*Applied on each pair of sacrifice iron electrode. 


\section{RESULTS AND DISCUSSION}

Table 2 presents the results of tests for color removal and concentration of residual iron by experimental design matrix execution. It should be noted that the data presented are mean values, because the tests were performed in duplicate.

Table 2. Experimental design matrix and results for color removal and concentration of residual iron.

\begin{tabular}{cccccc}
\hline Run & $\begin{array}{c}\mathrm{I} \\
(\mathrm{A})\end{array}$ & $\begin{array}{c}\text { MO } \\
\left(\mathrm{mg} \mathrm{L}^{-1}\right)\end{array}$ & $\begin{array}{c}\text { HRT } \\
(\mathrm{min})\end{array}$ & $\begin{array}{c}\text { Color removal } \\
(\%)\end{array}$ & $\begin{array}{c}\text { Concentration of residual iron } \\
\left(\mathrm{mg} \mathrm{L}^{-1}\right)\end{array}$ \\
\hline $\mathbf{1}$ & $-1(0.28)$ & $-1(282.1)$ & $-1(6)$ & $76.92 \pm 7.63$ & $7.847 \pm 0.013$ \\
$\mathbf{2}$ & $+1(0.82)$ & $-1(282.1)$ & $-1(6)$ & $86.80 \pm 0.74$ & $3.806 \pm 0.054$ \\
$\mathbf{3}$ & $-1(0.28)$ & $+1(817.9)$ & $-1(6)$ & $73.89 \pm 0.01$ & $6.539 \pm 0.343$ \\
$\mathbf{4}$ & $+1(0.82)$ & $+1(817.9)$ & $-1(6)$ & $36.01 \pm 3.50$ & $6.732 \pm 0.813$ \\
$\mathbf{5}$ & $-1(0.28)$ & $-1(282.1)$ & $+1(9)$ & $81.94 \pm 1.24$ & $7.241 \pm 0.610$ \\
$\mathbf{6}$ & $+1(0.82)$ & $-1(282.1)$ & $+1(9)$ & $65.20 \pm 0.22$ & $3.702 \pm 0.241$ \\
$\mathbf{7}$ & $-1(0.28)$ & $+1(817.9)$ & $+1(9)$ & $50.28 \pm 0.35$ & $8.107 \pm 0.314$ \\
$\mathbf{8}$ & $+1(0.82)$ & $+1(817.9)$ & $+1(9)$ & $23.91 \pm 2.15$ & $7.317 \pm 0.552$ \\
$\mathbf{9}$ & $0(0.55)$ & $0(550)$ & $0(7.5)$ & $56.14 \pm 2.20$ & $8.492 \pm 0.149$ \\
$\mathbf{1 0}$ & $0(0.55)$ & $0(550)$ & $0(7.5)$ & $53.41 \pm 0.53$ & $7.066 \pm 0.179$ \\
$\mathbf{1 1}$ & $0(0.55)$ & $0(550)$ & $0(7.5)$ & $57.89 \pm 0.46$ & $7.072 \pm 1.326$ \\
$\mathbf{1 2}$ & $+1.68(1.00)$ & $0(550)$ & $0(7.5)$ & $90.25 \pm 2.14$ & $8.209 \pm 0.942$ \\
$\mathbf{1 3}$ & $-1.68(0.10)$ & $0(550)$ & $0(7.5)$ & $8.46 \pm 3.39$ & $3.871 \pm 0.198$ \\
$\mathbf{1 4}$ & $0(0.55)$ & $+1.68(1000)$ & $0(7.5)$ & $72.37 \pm 0.45$ & $7.478 \pm 0.188$ \\
$\mathbf{1 5}$ & $0(0.55)$ & $-1.68(100)$ & $0(7.5)$ & $20.66 \pm 1.36$ & $9.031 \pm 2.658$ \\
$\mathbf{1 6}$ & $0(0.55)$ & $0(550)$ & $+1.68(10)$ & $71.77 \pm 0.63$ & $5.332 \pm 0.140$ \\
$\mathbf{1 7}$ & $0(0.55)$ & $0(550)$ & $-1.68(5)$ & $58.08 \pm 0.81$ & $8.447 \pm 0.031$ \\
\hline
\end{tabular}

Table 2 shows that the color removal ranged from $8.46 \%$ to $90.25 \%$. In addition, the concentration of residual iron ranged from $3.70 \mathrm{mg} \mathrm{L}^{-1}$ to $9.03 \mathrm{mg}$. L $\mathrm{L}^{-1}$. Based on Brazilian legislation (Conama, 2011), the dissolved iron concentration limit for effluent discharge in water bodies is $15 \mathrm{mg}$. $\mathrm{L}^{-1}$. This threshold was conformed to in all tests. The results obtained in this work with the hybrid treatment system are similar to those reported in the literature.

A techno-economic comparative between the use of chemical coagulants/flocculants and electrocoagulation in the treatment of textile industry wastewater was conducted. In this work the operating parameters analyzed were: $\mathrm{pH}$, electric current density and time of electrolysis. Total Organic Carbon (TOC) and organic dye removal were used to evaluate treatment performance, in addition to energy and electrode consumption. In accordance with the optimal parameters found in this study, the percentage of removal achieved were $81 \%$ for COD, $85 \%$ for TOC, $93 \%$ for turbidity and $97.1 \%$ for Total Suspended Solids (TSS). The results showed that despite the costs of power, the electrochemical treatment minimized the production of sludge, which decreased the costs of the process.

The optimum operating conditions to maximize the percentage removal of color and turbidity from washing jeans effluent was found (Ströher et al., 2012). The process parameters studied were: fast mixing time (ranged from 2 to 5 minutes), slow mixing time (from 20 to 30 minutes), and sedimentation time (from 20 to 30 minutes), with agitation fixed at $95 \mathrm{rpm}$ for coagulation and $30 \mathrm{rpm}$ for flocculation. The natural coagulant concentrations added were 1400 , 1600, 1800, 2000, 2200, 2400 and $2600 \mathrm{mg} \mathrm{L}^{-1}$. After coagulation/flocculation runs in Jar Test, the parameters of color and turbidity were analyzed and presented removals greater than $80.33 \%$ and $91,10 \%$, respectively.

The variables that influence the efficiency of color removal from an azo dye solution (Reactive Black 5 - RB 5) by the combination of ozonation and electrocoagulation with iron electrodes were investigated (Song et al., 2013). Various parameters were evaluated, such as 
initial $\mathrm{pH}$, initial dye concentration, electrical current density, salt concentration, temperature, ozone flow rate and distance between electrodes. The experimental results showed that the color of RB 5 in the aqueous phase was removed effectively. Under the conditions of initial dye concentration of $100 \mathrm{mg} \mathrm{L}^{-1}$, initial $\mathrm{pH}$ of 5.5 , electrical current density of $10 \mathrm{~mA} \mathrm{~cm} \mathrm{~cm}^{-2}$, salt concentration of $5000 \mathrm{mg} \mathrm{L}-1$, temperature of $20{ }^{\circ} \mathrm{C}$, ozone flow rate of $20 \mathrm{~mL} \mathrm{~min}^{-1}$ and distance between electrodes of $1 \mathrm{~cm}$, the removal efficiency of color reached 94\%, which corresponds to a COD reduction greater than $60 \%$.

The effects of operating parameters, such as $\mathrm{pH}$, initial dye concentration, electric current density, distance between electrodes and the electric conductivity in the treatment of a synthetic and real textile wastewater by electrocoagulation process were investigated (Merzouk et al., 2010). The optimal conditions, which were determined from synthetic wastewater treatment, were applied to a real textile effluent. Initially, various current densities were tested ranging from 11.55 to $91.5 \mathrm{~mA} \mathrm{~cm}^{-2}$ and the distances of the electrodes 1,2 and $3 \mathrm{~cm}$. The application of ideal operating parameters showed a high removal efficiency. The best results provided $85.5 \%$ of suspended solids removal, $76.2 \%$ of turbidity, $88.9 \%$ of Biochemical Oxygen Demand $\left(\mathrm{BOD}_{5}{ }^{20}\right), 79.7 \%$ of COD and $93 \%$ of color.

\subsection{Empirical Modeling of color removal promoted by treatment hybrid system}

Based on the results presented in Table 2, it was possible to evaluate the effects of the factors studied in response variable color removal. Analyzing Figure 2 (Pareto Diagram), it is possible to assess which of the terms relating to HRT was statistically significant $(5 \%$ significance level), then these terms were excluded from the model and their contributions were incorporated into residuals. Despite the fact that the terms quadratics and the interaction between electric current intensity and concentration of Moringa Oleífera Lam coagulant have not been significant, these terms were kept in the model.

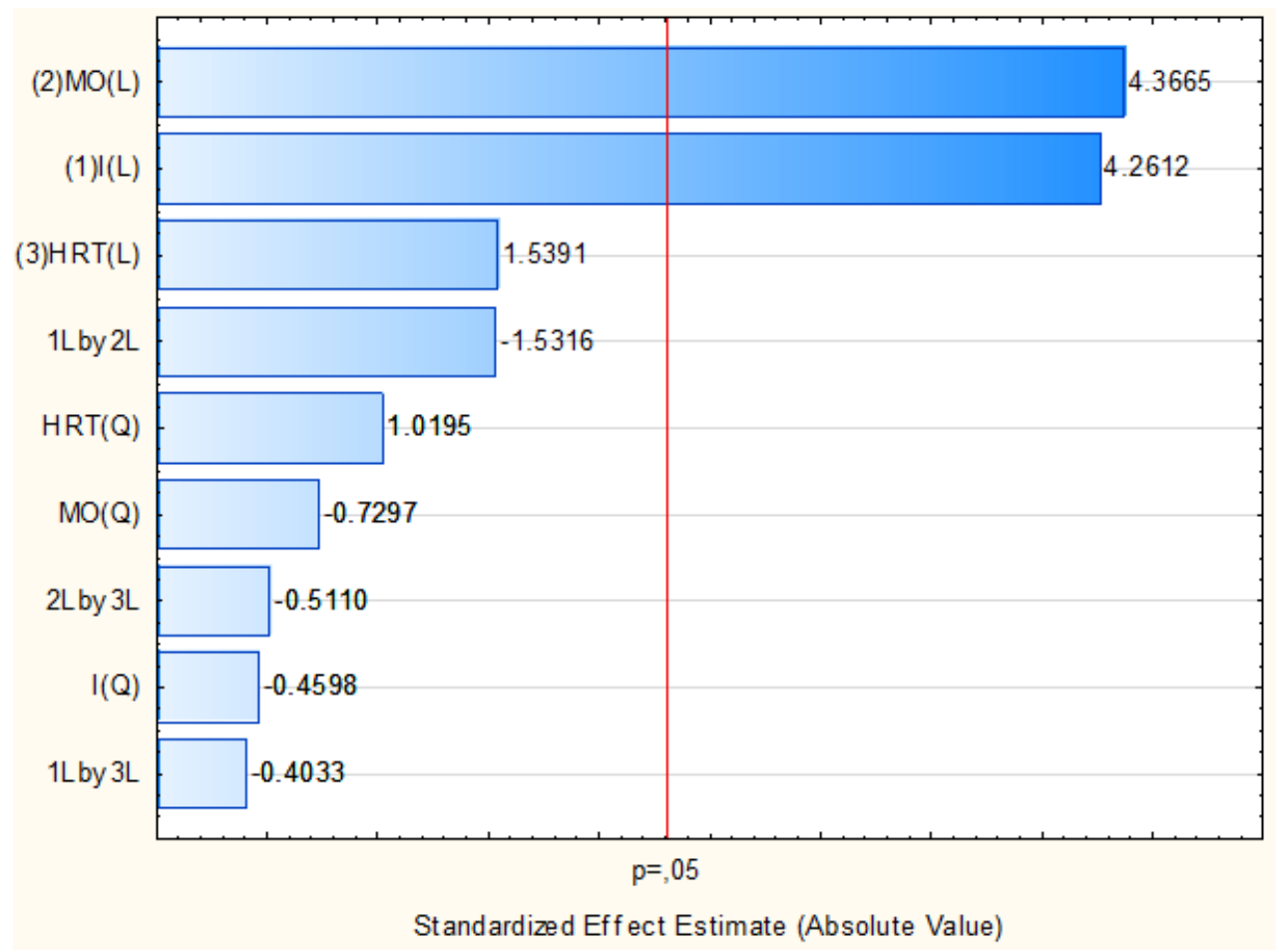

Figure 2. Pareto Diagram for color removal response.

Table 3 presents the regression coefficients of the model adjusted for color removal response.

Rev. Ambient. Água vol. 14 n. 3, e2290 - Taubaté 2019 
Table 3. Regression coefficients for the model of color removal response.

\begin{tabular}{lcccc}
\hline & Effects & Coefficients & Standard Error & p-value \\
\hline Mean & & 61.7628 & 5.8518 & $4.3 \mathrm{E}-07$ \\
$\mathrm{I}$ & 30.5623 & 15.2812 & 3.6604 & 0.0016 \\
$\mathrm{I}^{2}$ & -3.8291 & -1.9145 & 3.8540 & 0.6291 \\
MO & 31.3174 & 15.6587 & 3.6604 & 0.0013 \\
MO $^{2}$ & -5.8427 & -2.9213 & 3.8539 & 0.4644 \\
I.MO & -14.3465 & -7.1732 & 4.7805 & 0.1616 \\
\hline
\end{tabular}

Table 4 presents the ANOVA for color removal response. At under a 5\% significance level, the adjusted model is valid, with a determination coefficient of $77.85 \%$.

Table 4. ANOVA for color removal response.

\begin{tabular}{lllllll}
\hline $\begin{array}{l}\text { Source of } \\
\text { Variation }\end{array}$ & $\begin{array}{l}\text { Sum of } \\
\text { Squares }\end{array}$ & $\begin{array}{l}\text { Degrees of } \\
\text { Freedom }\end{array}$ & $\begin{array}{l}\text { Mean } \\
\text { Squares }\end{array}$ & $\mathbf{F}_{\text {calculated }}$ & $\begin{array}{l}\mathbf{F}_{\text {tabulated }} \\
\mathbf{F}_{\mathbf{0 . 0 5} ; 5 ; 11}\end{array}$ & p-value \\
\hline Regression & 7068.855 & 5 & 1413.771 & 7.733 & 3.204 & 0.0024 \\
Residual & 2011.049 & 11 & 182.823 & & & \\
Total & 9079.904 & 16 & & & & \\
\hline
\end{tabular}

$\mathrm{R}^{2}=77.85 \%$.

Figure 3 presents the surface response for color removal, setting the HRT at -1.68 (encoded value), or 5 min (real value).

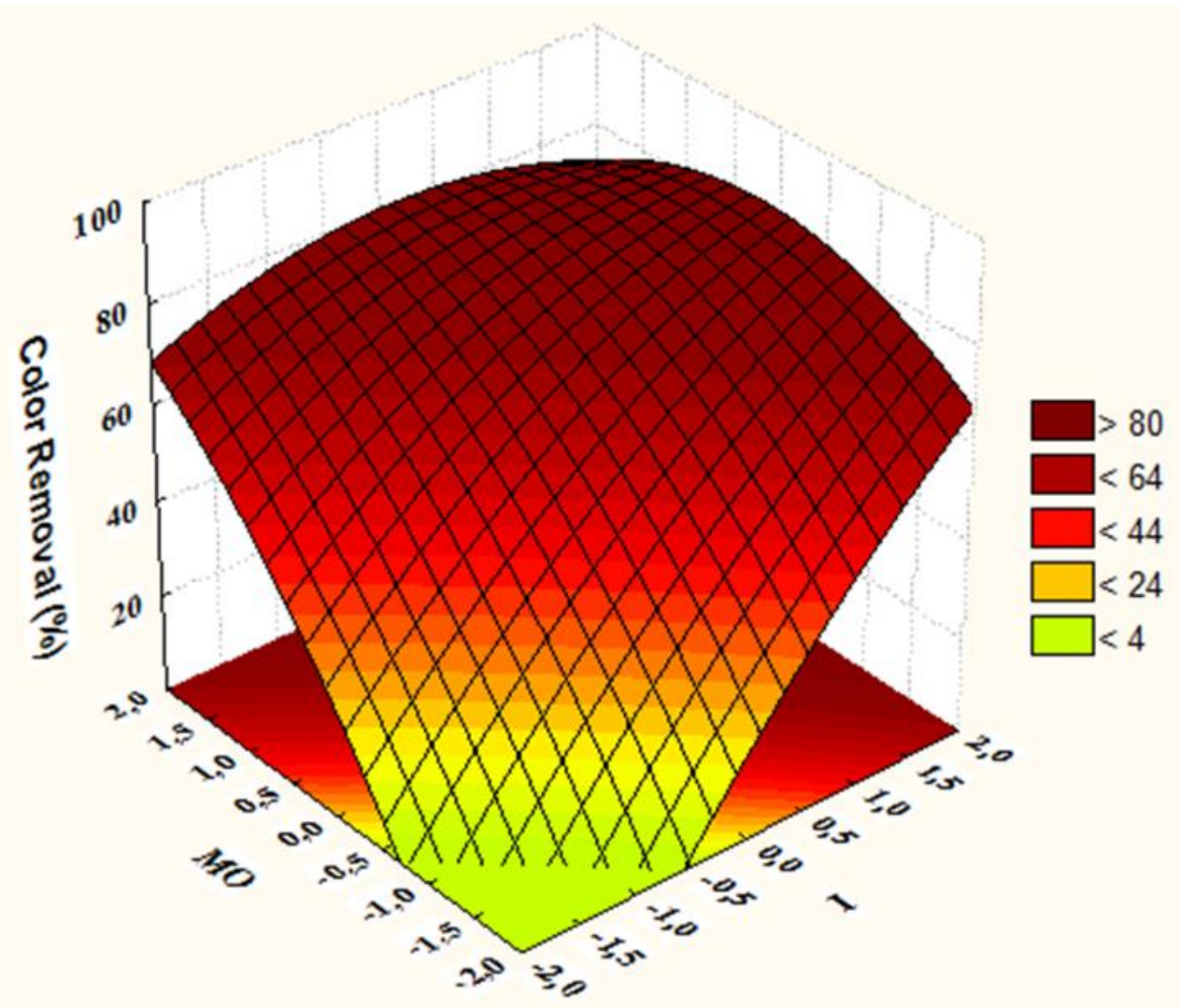

Figure 3. Surface response for color removal. 


\subsection{Empirical Modeling of concentration of residual iron}

Based on the data presented in Table 2, the ANOVA for concentration of residual iron response was made. The results confirmed the statistical analysis performed for color removal response, where the model terms relating to HRT were not significant, under a 5\% significance level. The effects of standardized terms can be observed in the Pareto Diagram (Figure 4).

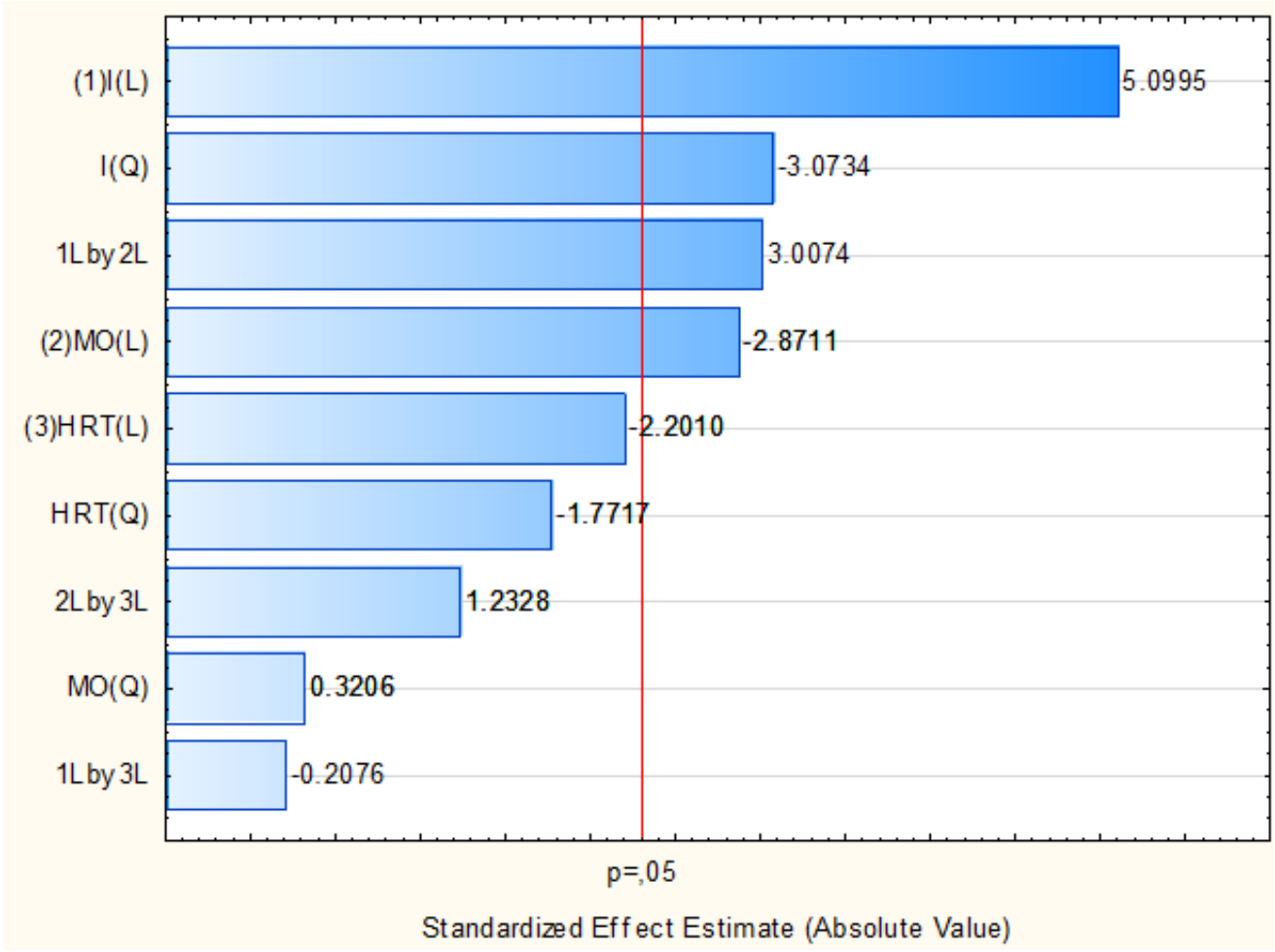

Figure 4. Pareto Diagram for concentration of residual iron response.

The terms relating to HRT were excluded from the model of concentration of residual iron, and their contributions were incorporated into residuals. The remaining terms were kept in the model. Table 5 shows the regression coefficients.

Table 5. Regression coefficients for concentration of residual iron response.

\begin{tabular}{lcccc}
\hline & Effects & Coefficients & Standard error & $\mathrm{p}$ - value \\
\hline Mean & & 7.1129 & 0.4344 & $4.5 \mathrm{E}-09$ \\
$\mathbf{I}$ & 2.2666 & 1.1333 & 0.2718 & 0.0016 \\
$\mathbf{I}^{\mathbf{2}}$ & -1.1239 & -0.5619 & 0.2861 & 0.0753 \\
MO & -1.2761 & -0.6382 & 0.2718 & 0.0386 \\
MO $^{2}$ & 0.4452 & 0.2227 & 0.2861 & 0.4530 \\
I.MO & 1.7457 & 0.8729 & 0.3549 & 0.0317 \\
\hline
\end{tabular}

Table 6 presents the ANOVA for the concentration of residual iron response. It appears that for a 5\% significance level, the adjusted model is valid, with a determination coefficient of $75.76 \%$.

Figure 5 presents the surface response for concentration of residual iron, setting the HRT at -1.68 (encoded value), or $5 \mathrm{~min}$ (real value). According to the surface response, the lowest values for concentration of residual iron are achieved when a high dose of aqueous extract of Moringa Oleífera Lam is used and low values of electric current intensity are employed. 
Table 6. ANOVA for concentration of residual iron response.

\begin{tabular}{lllllll}
\hline $\begin{array}{l}\text { Source of } \\
\text { Variation }\end{array}$ & $\begin{array}{l}\text { Sum of } \\
\text { Squares }\end{array}$ & $\begin{array}{l}\text { Degrees of } \\
\text { Freedom }\end{array}$ & $\begin{array}{l}\text { Mean } \\
\text { Squares }\end{array}$ & F calculated & $\begin{array}{l}\mathbf{F}_{\text {tabulated }} \\
\mathbf{F}_{\mathbf{0 . 0 5} ; 5 ; 1}\end{array}$ & p-value \\
\hline Regression & 34.655 & 5 & 6.931 & 6.878 & 3.204 & 0.0038 \\
$\begin{array}{l}\text { Residual } \\
\text { Total }\end{array}$ & 11.085 & 11 & 1.008 & & & \\
\hline
\end{tabular}

$\mathrm{R}^{2}=75,76 \%$.

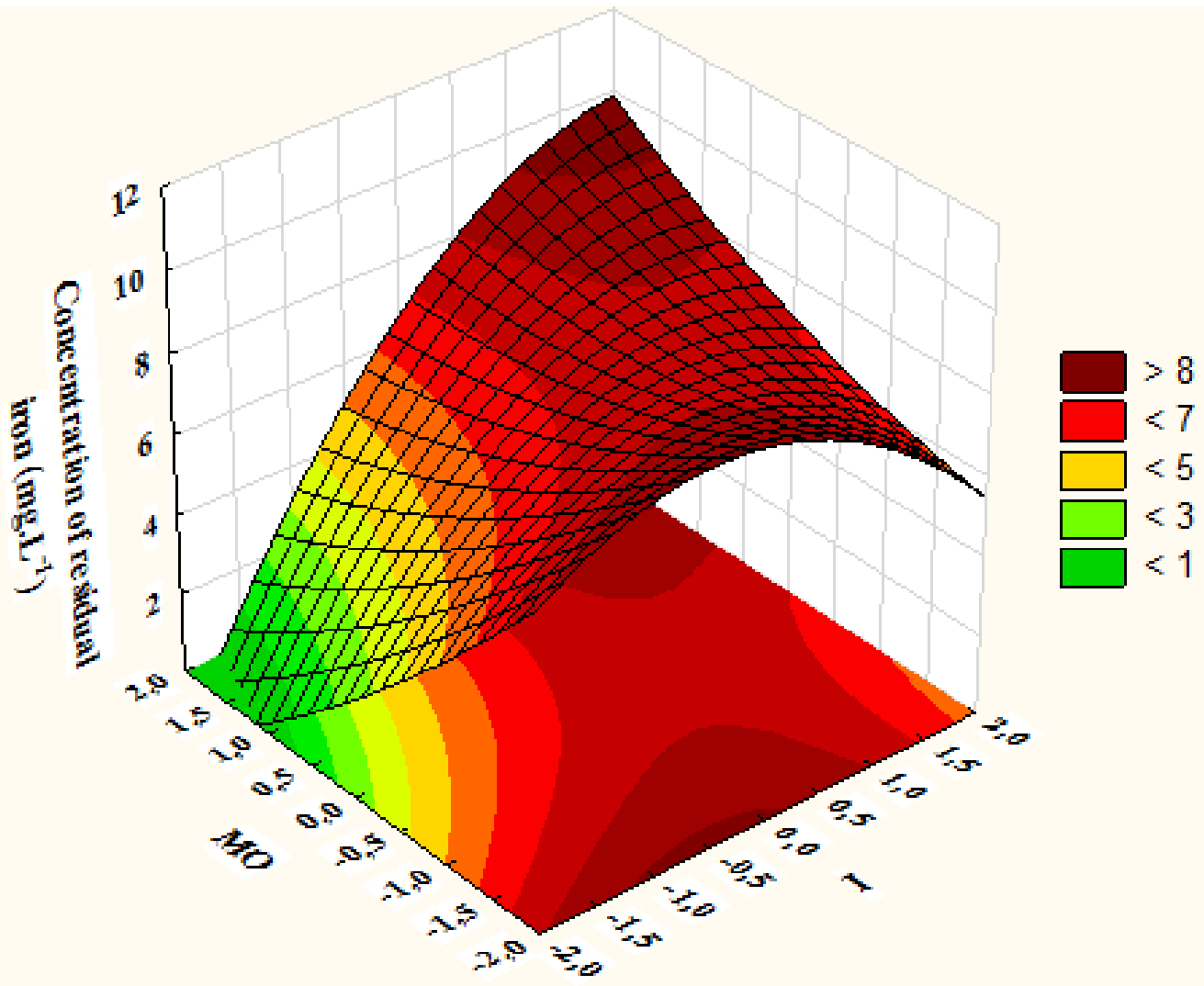

Figure 5. Surface response for concentration of residual iron.

\subsection{Overall Optimization of hybrid treatment system and validation of empirical modeling}

The optimal values of operating conditions for hybrid treatment system were found using the desirability function of Statistica ${ }^{\mathrm{TM}}$ software. This optimization tool searches for a unique solution, which satisfies both the maximization of color removal and the minimization of concentration of residual iron.

Figure 6 shows the optimum range of operating conditions obtained by the superposition of level curves for the responses evaluated in electrocoagulation tests in continuous flow. The best overall results were achieved with an electric current intensity of $0.28 \mathrm{~A}$ (encoded value of-1) and concentration of Moringa Oleífera Lam extract of $1000.00 \mathrm{mg} \mathrm{L}^{-1}$ (encoded value of $+1,68)$. The HRT could be set at the minimum value $(5 \mathrm{~min})$, since it had no effect on the responses of the process. 

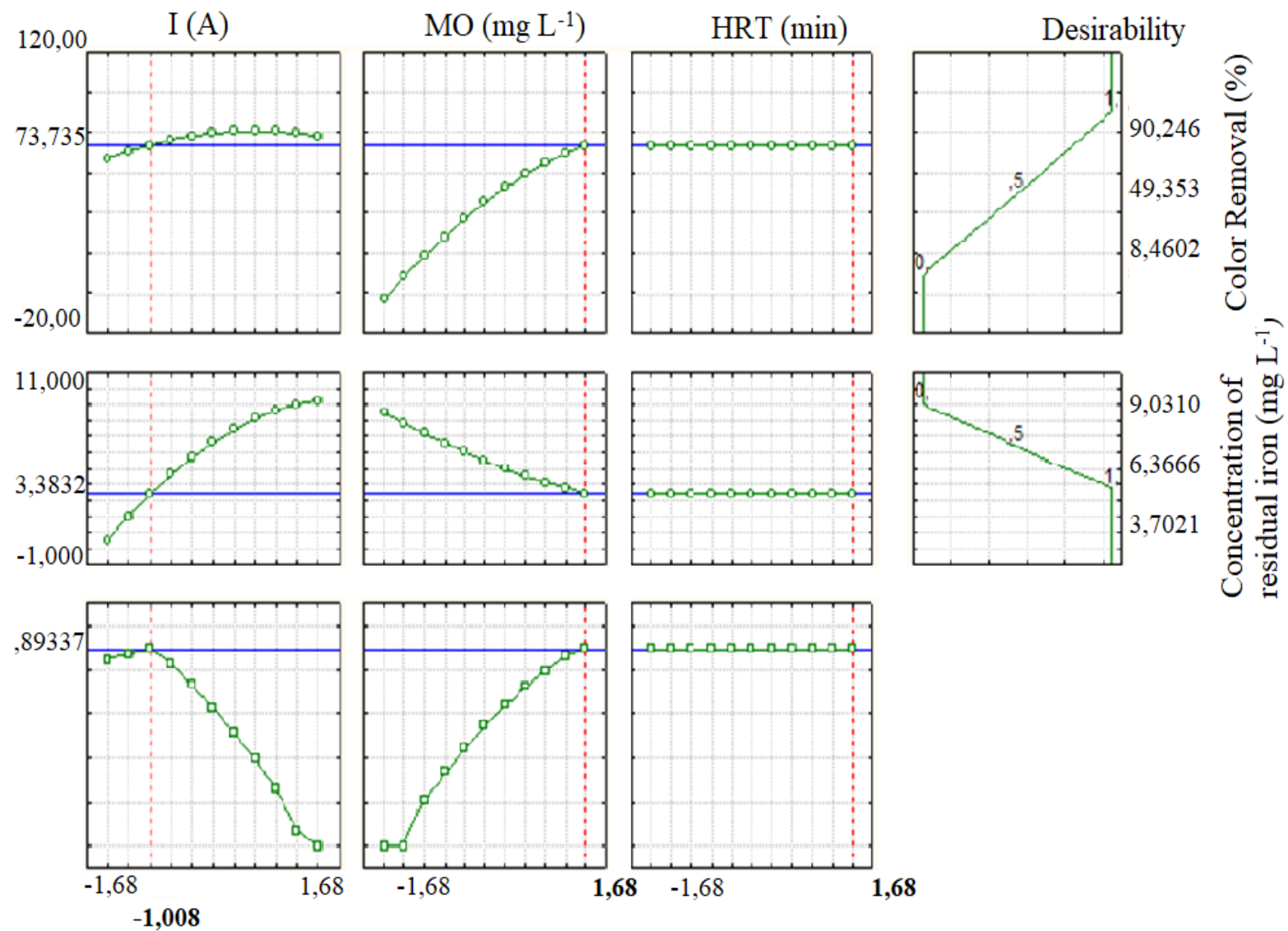

Figure 6. Overall optimization conditions for the hybrid treatment system.

After the optimal setting for the hybrid treatment system had been defined, the validation test was performed in triplicate. Table 7 presents the mean values of color removal and concentration of residual iron responses, in addition to the prediction errors of adjusted models.

Table 7. Validation test of models for color removal and concentration of residual iron.

\begin{tabular}{lccc} 
Response & Predicted Value & Mean Value Observed & Mean Error \\
\hline Color removal (\%) & 74.68 & $71.38 \pm 1.44$ & $4.62 \%$ \\
Concentration of residual iron $\left(\mathrm{mg} \mathrm{L}^{-1}\right)$ & 3.5076 & $5.2237 \pm 0.1069$ & $32.85 \%$
\end{tabular}

The results presented in Table 7 show that the model adjusted for color removal response can be used as a predictive model, because the presented mean error was less than $5 \%$. However, the model for concentration of residual iron response presented high prediction error. The efficiency of hybrid treatment system was considered satisfactory, once it removed more than $70 \%$ of the color of Reactive Blue $5 \mathrm{G}$ dye solution, and the concentration of residual iron remained within allowable limits by Brazilian legislation (15 mg L $\left.\mathrm{L}^{-1}\right)$ (Conama, 2011).

Moreover, the association electrocoagulation with natural coagulant addition (Moringa Oleífera Lam extract) provided an interesting hybrid treatment system. Using both treatment technologies, it was possible to reduce the electric current intensity required, which is important for energy saving. Table 8 presents a summary of other study results for comparison. 
Table 8. Treatment performance comparison.

$\begin{array}{lll}\text { Reference } & \text { Better results } & \text { Operating Conditions details }\end{array}$

\begin{tabular}{|c|c|c|}
\hline $\begin{array}{l}\text { (Daneshvar et al., } \\
\text { 2006) }\end{array}$ & $\begin{array}{l}\text { Almost } 100 \% \text { of color removal from } \\
\text { dye mixture }\end{array}$ & $\begin{array}{l}6 \text { a } 8 \mathrm{~mA} \mathrm{~cm}^{-2} \text {; Batch experiments; } \\
5 \mathrm{~min} \text { of electrolysis; } 250 \mathrm{~mL} \text { dye } \\
\text { solution treated }\end{array}$ \\
\hline (Song et al., 2007) & $\begin{array}{l}\text { Color removal of } 94 \% \text { and more than } \\
60 \% \text { of COD from Reactive Black } 5 \\
\text { dye solution }\end{array}$ & $\begin{array}{l}10 \mathrm{~mA} \mathrm{~cm}^{-2} \text { associated with } 20 \mathrm{~mL} \\
\text { min }^{-1} \text { of ozone flow rate; Batch } \\
\text { experiments with continuous } \\
\text { ozone feed; } 15 \mathrm{~min} \text { of time } \\
\text { reaction; } 250 \mathrm{~mL} \text { of dye solution } \\
\text { treated (treatment efficiency } \\
\text { evaluated after samples } \\
\text { centrifugation) }\end{array}$ \\
\hline
\end{tabular}

(Yuksel et al., 2011) Color removal of $99.9 \%$ from Reactive $4 \mathrm{~mA} \mathrm{~cm}^{-2}$; Batch experiments; 1.5 Yellow RY 135 solution L of dye solution treated; $10 \mathrm{~min}$ of electrolysis

\begin{tabular}{|c|c|c|}
\hline (Merzouk et al., 2010) & $\begin{array}{l}89.6 \% \text { of turbidity removal from } \\
\text { synthetic wastewater } \\
85.5 \% \text { of SS, } 76.2 \% \text { of turbidity, } 88.9 \% \\
\text { of BOD, } 79.7 \% \text { of COD and } 93 \% \text { of } \\
\text { color removal from real textile } \\
\text { wastewater }\end{array}$ & $\begin{array}{l}11.55 \quad \mathrm{~mA} \mathrm{~cm}^{-2} ; \quad \text { Batch } \\
\text { experiments; } 10 \text { min of } \\
\text { electrolysis; 1 L of wastewater } \\
\text { treated }\end{array}$ \\
\hline (Mondal et al., 2013) & $\begin{array}{l}99.7 \% \text { of color removal and } 94 \% \text { of } \\
\text { COD removal from an azo dye solution }\end{array}$ & $\begin{array}{l}19.51 \mathrm{~mA} \mathrm{~cm}^{-2} ; \\
\text { experiments; } 102 \text { min of } \\
\text { electrolysis; } 2 \mathrm{~L} \text { of textile } \\
\text { wastewater treated }\end{array}$ \\
\hline (Valero et al., 2008) & $\begin{array}{l}\text { Color removal of } 99.3 \% \text { from Remazol } \\
\text { Red RB } 133 \text { dye solution }\end{array}$ & $\begin{array}{l}10 \mathrm{~mA} \mathrm{~cm}^{-2} ; \quad \text { Continuous } \\
\text { electrochemical reactor; } 250 \mathrm{~mL} \\
\text { of dye solution; } 23 \mathrm{~min} \text { of } \\
\text { electrolysis }\end{array}$ \\
\hline \multirow{2}{*}{ Current Paper } & $\begin{array}{l}\text { Better Results: Color removal of } \\
90.25 \% \text { and concentration of residual } \\
\text { iron of } 8.2 \mathrm{mg} \mathrm{L}^{-1} \text {. }\end{array}$ & $\begin{array}{l}3.31 \mathrm{~mA} \mathrm{~cm}^{-2} \text { associated with } 550 \\
\mathrm{mg} \mathrm{L}^{-1} \text { of Moringa Oleífera Lam } \\
\text { coagulant; continuous } \\
\text { electrochemical reactor; } \\
16 \mathrm{~L} \text { of dye solution treated; } 5 \mathrm{~min} \\
\text { of electrolysis }\end{array}$ \\
\hline & $\begin{array}{l}\text { Overall optimized conditions: Color } \\
\text { removal of } 71.38 \% \text { and concentration } \\
\text { of residual iron of } 5.2 \mathrm{mg} \mathrm{L}^{-1} \text {. }\end{array}$ & $\begin{array}{l}0.93 \mathrm{~mA} \mathrm{~cm}-2 \text { associated with } \\
1000 \mathrm{mg} \mathrm{L}^{-1} \text { of Moringa Oleífera } \\
\text { Lam coagulant. Continuous } \\
\text { electrochemical reactor; } 16 \mathrm{~L} \text { of } \\
\text { dye solution treated; } 5 \mathrm{~min} \text { of } \\
\text { electrolysis. }\end{array}$ \\
\hline
\end{tabular}

Despite the different wastewaters tested, the current work used the least electric current and processed the largest volume of effluent. 


\section{CONCLUSIONS}

The technique of electrocoagulation associated with the addition of Moringa Oleífera Lam extract applied in continuous flow presented excellent results for the removal of color, reaching a percentage of $90.25 \%$ for Reactive Blue $5 \mathrm{G}$ dye solutions. The concentration of residual iron was monitored for the effluent from the hybrid treatment system, and showed values from 3.702 to $9.031 \mathrm{mg} \mathrm{L}^{-1}$ (below the permissible limit by Brazilian legislation).

The overall optimization of the hybrid treatment system has been proceeding successfully. As a result of this analysis, electric current intensity of $0.28 \mathrm{~A}$ was achieved, at a concentration of Moringa Oleífera Lam extract of $1000.00 \mathrm{mg} \mathrm{L}^{-1}$ and a hydraulic retention time of 5 minutes. Tests using the optimal setting provided color mean removal of $71.38 \%$ and mean concentration of residual iron of $5.2237 \mathrm{mg} \mathrm{L}^{-1}$.

The models adjusted for removal color and concentration of residual iron responses were validated statistically by ANOVA; however, only the model for color removal presented satisfactory results as a predictive model, because the prediction error evaluated was less than $5 \%$, while the model for the concentration of residual iron response provided mean prediction error greater than $30 \%$.

\section{ACKNOWLEDGMENTS}

This work was supported by the Fundação Araucaria, Fundação Parque Tecnológico Itaipú - Brasil and CNPq.

\section{REFERENCES}

ADJEROUD, N.; DAHMOUNE, F.; MERZOUK, B.; LECLERC, J.P.; MADANJ, K. Improvement of electrocoagulation-electroflotation treatment of effluent by addition of Opuntia ficusindica pad juice. Separation and Purification Technology, v. 144, p. 168176, 2015. https://doi.org/10.1016/j.seppur.2015.02.018

AQUINO NETO, S.; MAGRI, T. C.; SILVA, G. M.; ANDRADE, A. R. Tratamento de Resíduos de Corante por Eletrofloculação: Um Experimento para Cursos de Graduação em Química. Química Nova, v. 34, p. 1468-1471, 2011. https://doi.org/10.1590/S010040422011000800030

ARANTES, C. C.; RIBEIRO, T. A. P.; PATERNIANI, J. E. S. Processamento de sementes de Moringa oleífera utilizando-se diferentes equipamentos para obtenção de solução coagulante. Revista brasileira de Engenharia Agrícola e Ambiental, v. 16, p. 661-666, 2012.

ASAITHAMBI, P.; SUSREE, M.; SARAVANATHAMIZHAN, R.; MATHESWARAN, M. Ozone assisted electrocoagulation for the treatment of distillery effluent. Desalination, v. 297, p. 1-7, 2012. https://doi.org/10.1016/j.desal.2012.04.011

BARRETO, M. B.; FREITAS, J. V. B.; SILVEIRA, E. R. Constituintes químicos voláteis e não voláteis de Moringa oleífera Lam, Moringaceae. Revista Brasileira de Farmacognosia, v. 19, p. 893-897, 2009.

BAZRAFSHAN, E.; MOSTAFAPOUR, F.K.; FARZADKJA, M.; OWNAGH, K.A.; MAHVI, A. H. Slaughterhouse wastewater treatment by combined chemical coagulation and electrocoagulation process. Plos One, v. 7, n. 6, p. e40108, 2012. https://doi.org/10.1371/journal.pone.0040108 
CARVALHO, R. M.; PAIVA, J. F. de; GUEDES, C. D. Clarificação de águas pluviais ricas em óxidos de ferro acumuladas em cava de mineração através da utilização de um coagulante natural, a Moringa oleífera. Revista Brasileira de Recursos Hídricos, v. 11, p. 59-67, 2006.

CONAMA (Brasil). Resolução No 430 de 13 de maio de 2011. Dispõe sobre as condições e padrões de lançamento de efluentes, complementa e altera a Resolução no 357, de 17 de março de 2005, do Conselho Nacional do Meio Ambiente-CONAMA. Diário Oficial [da] União, n. 92, p. 89, 16 maio 2011.

DANESHVAR, N.; OLADEGARAGOZE, A.; DJAFARZADEH, N. Decolorization of basic dye solution by electrocoagulation: An investigation of the effect of operational parameters. Journal of Hazardous Materials, v. 129, p. 116-122, 2006. https://doi.org/10.1016/j.jhazmat.2005.08.033

LAMBRECHT, R.; BARROS, de M.A.S.D.; BORBA, C.E.; SILVA, E.A. Adsorption of the dye reactive blue 5G in retorted shale. Brazilian Journal of Chemical Engineering, $\mathrm{V}$. 32, p. 269-281, 2015. http://dx.doi.org/10.1590/0104-6632.20150321s00001715

MERZOUK, B.; MADANI, K.; SEKKI, A. Using electrocoagulation-electroflotation technology to treat synthetic solution and textile wastewater, two case studies. Desalination, v. 250, p. 573-577, 2010. https://doi.org/10.1016/j.desal.2009.09.026

MONDAL, B.; SRIVASTAVA, V. C.; KUSHWAHA, J. P.; BHATNAGAR, R.; SINGH, S.; MALL, I. D. Parametric and multiple response optimization for the electrochemical treatment of textile printing dye-bath effluent. Separation and Purification Technology, v. 109, p. 135-143, 2013. https://doi.org/10.1016/j.seppur.2013.02.026

PAJOOTAN, E.; MOKHTAR, A.; NIYAZ, M. M. Binary system dye removal by electrocoagulation from synthetic and real colored wastewaters. Journal of the Taiwan Institute of Chemical Engineers, v. 43, n. 2, p. 282-290, 2012. https://doi.org/10.1016/j.jtice.2011.10.014

PATERNIANI, J. E. S.; MANTOVANI, M. C; SANT'ANNA, M. R. Uso de sementes de Moringa oleifera para tratamento de águas superficiais. Revista Brasileira de

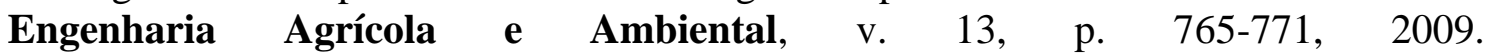
https://dx.doi.org/10.1590/S1415-43662009000600015

RASCHITOR, A.; FERNANDEZ, C. M.; CRETESCU, I.; RODRIGO, M. A.; CAÑIZARES, P. Sono-electrocoagulation of wastewater polluted with Rhodamine 6G. Separation and $\begin{array}{llllll}\text { purification technology, } & \text { v. } 135, \quad \text { p. } & 110-116,\end{array}$ https://doi.org/10.1016/j.seppur.2014.08.003

SECULA, M. S.; CAGNON, B.; OLIVEIRA, T. F.; CHEDEVILLE, O.; FAUDUET, H. Removal of acid dye from aqueous solutions by electrocoagulation/GAC adsorption coupling: Kinetics and electrical operating costs. Journal of the Taiwan Institute of $\begin{array}{llllllll}\text { Chemical Engineers, } & \text { v. } 43, \quad \text { n. } & \text { 5, } & \text { p. }\end{array}$ https://doi.org/10.1016/j.jtice.2012.03.003

SONG, S.; HE, S.; QIU, J.; XU, L.; CHEN, J. Ozone assisted electrocoagulation for decolorization of C.I. Reactive Black 5 in aqueous solution: An investigation of the effect of operational parameters. Separation and Purification Technology, v. 55, p. 238-245, 2007. https://doi.org/10.1016/j.seppur.2006.12.013 
STRÖHER, A. P.; COUTO JUNIOR, O. M.; MENEZES, M. L.; BERGAMASCO, R.; PEREIRA, N. C. Aplicação de moringa oleífera lam no tratamento de efluente proveniente da lavagem de jeans. Exacta, v. 5, p. 61-66, 2012.

VALERO, D.; ORTIZ, J. M.; EXPÓSITO, E.; MONTIEL, V.; ALDAZ, A. Electrocoagulation of a synthetic textile effluent powered by photovoltaic energy without batteries: direct connection behavior. Solar Energy Materials \& Solar Cells, v. 92, p. 291-297, 2008. https://doi.org/10.1016/j.solmat.2007.09.006

VIANNEY, M. J. M.; MUTHUKUMAR, K. Studies on Dye Decolorization by Ultrasound Assisted Electrocoagulation. Clean-Soil, Air, Water, v. 44, n. 3, p. 232-238, 2016. https://doi.org/10.1002/clen.201400011

YAVUZ, Y.; SHAHBAZI, R.; KOPARAL, A. S.; ÖĞÜTVEREN, Ü. B. Treatment of Basic Red 29 dye solution using iron-aluminum electrode pairs by electrocoagulation and electro-Fenton methods. Environmental Science and Pollution Research, v. 21, n. 14, p. 8603-8609, 2014. https://doi.org/10.1007/s11356-014-2789-8

YUKSEL, E.; GURBULAK, E.; EYVAZ, M. Decolorization of a Reactive Dye Solution and Treatment of a Textile Wastewater by Electrocoagulation and Chemical Coagulation: Techno-Economic Comparison. Environmental Progress \& Sustainable Energy, v. 31, p. 524-535, 2011. https://doi.org/10.1002/ep.10574 